\title{
VILNIAUS TAPATUMO SLUOKSNIAI BRAUNO IR HOGENBERGO ATLASE
}

\author{
Lukas Rekevičius \\ Architektūros pagrindu ir teorijos katedra, Vilniaus Gedimino technikos universitetas, \\ Pylimo g. 26/Trakug. 1, 01132 Vilnius, Lietuva \\ El.paštaslukas@rekevicius.lt \\ Itteikta 20100125
}

\begin{abstract}
Santrauka. Analizuojama prielaida apie Brauno ir Hogenbergo atlaso Vilniaus plane perteikiamus miesto savitumų bruožus. Naudojant pasirinktą tapatumo struktūros modelį, analizuojama grafinèje ir tekstinèje atlaso dalyje pateikta informacija apie Vilnių. Ieškoma atlase pateiktų gamtinių (reljefo, vandenų, augmenijos), kultūrinių (socialinių, politinių, ekonominių, tautinių ir konfesinių), antropogeninių (urbanistinių, architektūrinių) Vilniaus savitumo apraiškų, pateikti Vilniaus ir kitų atlase pavaizduotų miestų palyginimai. Nustatyti plane atskleisti miesto urbanizacijos ypatumai, užstatymo tipai ir morfologija, miesto policentriškumas, miesto kaip sostinės bruožai, gyventojų grupių charakteristikos, taip pat rasta plano netikslumų konfesinio balanso, gatvių tinklo, miesto dydžio atžvilgiais.
\end{abstract}

Reikšminiai žodžiai: Brauno ir Hogenbergo atlasas, Vilniaus senamiestis, savitumas, tapatumas, ̣̂vaizdis.

\section{Ivadas}

Vilniaus miesto istorijos tyrimai tapatumo raidos klausimu yra gana fragmentiški ir prieštaringi. Iki XVI a. vidurio nera aptikto nei vieno ikonografinio ar kartografinio šaltinio, galinčio duoti teisingą ir išsamų supratimą apie to meto miesto vaizdą. Metas nuo miesto ịkūrimo $1323 \mathrm{~m}$. iki pirmojo miesto vaizdo pateikimo Miunsterio Cosmographia leidinyje yra nupasakojamas tik rašytiniuose šaltiniuose - Gilibero de Lanua aprašyme, kryžiuočių kelių aprašymuose (Wegeberichte), valdovų laiškuose. Paprastai ši medžiaga duoda tik apytikrị vaizdą - aprašomi pavieniai objektai, o tokios deskripcijos, kaip ilgai driekési i vakarus (Katalynas, Vaitkevičius 1995) arba yra ir mediniu, ir müriniu pastatu, yra informatyvios tik susidarant apytikrị vaizdą, kas tuo metu Vilniuje buvo, bet neduodančios daug žinių apie miesto urbanistinę sandarą, architektūros objektus ir stilius, gamtinį kontekstą, sociologinę (politinę, kultūrinę, ekonominę, tautinę ir konfesinę) aplinką. Neturime svarbios informacijos apie miestą supančias gretimybes - priemies- čius, kaimus, pavienius pastatus, todèl galime daryti tik apytiksles prielaidas dèl miesto infrastruktūros aprūpinimo maistu ir žaliavomis, kelių.

Medžiagos trūkumas skatina ịvairių hipotezių kūrimą apie pakitusį miesto gatvių tinklą (pvz., yra hipotezių ${ }^{1}$, jog Trakų vartai ir Bernardinų vartai kažkada buvo tiesiogiai sujungti vidine miesto gatve ir kad tai buvo svarbi jungtis tarp Trakų trakto ir dabar nebeišlikusio kelio per Altarijos kalvyną - ị rytinių LDK miestų pusę) arba kitus neišlikusius urbanistinius darinius (autoriaus keliama hipotezè, kad pleištiški 122, 123, 124, 125, 126 kvartalai, parodyti K. Grunerto $1808 \mathrm{~m}$. plane, galbūt žymi buvusios didesnès aikštès prie Šv. Jono bažnyčios kontūrus).

Vilnius iki pat XIX a. atvaizduotas nedaugelyje žemèlapių. Kartografinè medžiaga skurdi, nes čia niekada nejo itin svarbūs prekybos keliai.

\footnotetext{
${ }^{1}$ Nepublikuota medžiaga.
} 
Kartografinių šaltinių teikiama informacija yra palyginti mažai studijuota ir aprašyta perteikiamo miestovaizdžio tapatumo aspektu, todel bandymas suteikti miesto architektūros ir urbanistikos tyrimams dar vieną papildomą sluoksni gali vaisingai papildyti kituose mokslo baruose atliekamus kultūrologinius Vilniaus istorijos tyrimus.

Vilniaus tapatumo studijos menotyrine prasme gali turèti reikšmès ir kai kuriamos senosios miesto dalies apsaugos koncepcijos (specialieji planai, senamiesčio apsaugos reglamentai), ir kai dirbamas kūrybinis darbas atkuriant nunykusị senamiesčio užstatymą, nes pagal šiuolaikinę paveldosaugos koncepciją svarbu ne saugoti konkretų miesto praeities paveikslą ar jo ištrauką, o suvokti, palaikyti ir pratęsti miesto formavimosi logines grandines, neužkonservuojant senamiesčio konkrečiame laikmetyje. Todèl ypač svarbi miesto tapatumo raidos analizė, kuri turètų būti pratęsta straipsniais apie kitų epochų miesto savitumus.

Taigi itin svarbios pirmojo išsamaus Vilniaus ikonografinio, kartografinio šaltinio - Vilniaus miesto plano, pateikto Brauno ir Hogenbergo Civitates Orbis Terrarum atlaso $1581 \mathrm{~m}$. leidime, - studijos. Ši medžiaga padeda plačiau interperetuoti istorinius faktus, suvokti miestovaizdžio raidą, nušviečia miesto charakterị, genius loci (Norberg-Schulz 1980), kuriuo vadovaujantis šiandieną galime pratęsti Vilniaus senamiesčio ir gretimų teritorijų dinamišką pulsavimą praktikoje.

Pagrindinis straipsnio tikslas - pritaikyti pasirinktą tapatumo modeli, analizuojant Brauno bei Hogenbergo atlaso Vilniaus planą, ir nustatyti istoriniame šaltinyje perteikiamo miestovaizdžio savitumų kompleksą miesto tapatumą. Pasirinkta analizès pagal modeli metodika yra tinkama vertinti bet kokio bet kurio laikotarpio ar regiono miesto tapatumo sudeti pagal atskiras tapatumo elementų grupes: pagal gamtinius tapatumo ženklus, antropogeninius tapatumo ženklus, sociokultūrinius tapatumo ženklus. Metodika inovatyvi, apibendrinanti kitų autorių pasiūlytas metodikas: K. Lyncho antropogeninių tapatumo elementų klasifikaciją, C. Norberg-Schulzo pasiūlytą genius loci koncepciją, R. Buivydo semantinio gamtos elementu vaidmens tyrimus, V. Petrušonio vietovès kultūrinio tapatumo aprašymo prielaidas.

\section{Tapatumo sandara}

Vyrauja keletas tapatumo nusakymo teorijų. Filosofiniu požiūriu išskiriama keletas teorijų - ir statiškų, ir dinamiškų tapatumo modelių. Sociologiniu aspektu renkamasi dinamiškos tapatybès forma, kultūrologi- niu ir semiotiniu - statiška (kolektyvinè atmintis). Reikia atkreipti demesĭ, kad skirtingose teorijose kartojasi tam tikri archetipiniai elementai, formuojantys tapatumą: kalba, kultūra, teritorija, rasè, religija, istorija. Ypač svarbus šių elementų pastovumas laike, esantis dèl dinamiškų tapatybès apraiškų.

Kultūrinis tapatumas šiuo metu yra sparčiai kintantis fenomenas, tačiau archetipiniai nekintantys elementai kuria tautas, miestus ir valstybes. Kalba (ar kalbos), kultūra, teritorija, religija ir istorija susipina viename reikšmingame antropogeniniame darinyje, kuris yra tiek statiškas, tiek dinamiškas, - mieste. Miestovaizdis tampa priemone vietos kultūrai, religijai, istorijai, etniškumui aprašyti, vizualus tapatumas tampa prekès ženklu, o vizualiojo tapatumo orientyrai (landmarks pagal K. Lynchą) - tapatybès ženklai tampa viso identiteto suvokimo viršūne.

Kuriantis ir plečiantis miestui (nesvarbu, padrikai ar planuotai), besiformuojant miesto struktūrai ir erdvėms, kuriasi ne tik funkcija ar meno kompozicija, tačiau formuojasi ir miesto ịvaizdis. Šị ịvaizdị priima visi urbanizuotos teritorijos stebetojai: gyventojai, miesto svečiai, nuotoliniai virtualūs lankytojai (per televiziją, internetą). Miesto įvaizdis yra formuojamas simboliais, šie simboliai mieste yra architektūros ir urbanistikos objektai. Tačiau miesto ịvaizdis ir jo suvokimas neapsiriboja vien materialios išraiškos visuma. Reikia pabrèžti ir miesto jausmo svarbą, teoretiko Ch. NorbergSchulzo įvardintą kaip genius loci.

Pasak šio autoriaus, miesto erdvès charakterị apibūdina miesto dvasia (genius loci). Miesto erdvè yra nevienalyté, ji susideda iš daugelio lokaliai ir savarankiškai per tam tikrą laiką išsivysčiusių struktūrų. V. Petrušonis nurodo, kad kiekvienas miestas turi savo unikalų ịvaizdị (susidedantị iš vizualaus ịvaizdžio ir mentalinio įvaizdžio - genius loci), kuris yra nedalomas, nes kitaip neįmanoma iki galo suvokti miesto esmès. Pasak K. Lyncho, pagrindiniai miesto tapatumo jausmą formuojantys elementai yra šie:

- keliai (roads);

- ribos (boundaries);

- rajonai (districts);

- jungtys (joints);

- orientyrai (landmarks).

Tačiau šie nurodyti formantai yra tik antropogeninès kilmès, todèl sąrašą būtina papildyti gamtinių tapatumo ženklų komponentais. Taip pat dera pamėginti struktūruoti efemerišką ",miesto dvasios“ elementą ir išskirti jị kaip miesto kultūrinị klimatą formuojančių aspektų rinkinị (kultūrinis kontekstas). 
Atsižvelgiant ị anksčiau išdèstytas teorijas, Vilniaus tapatumas, perteikiamas Brauno ir Hogenbergo atlaso žemèlapyje, gali būti aprašytas suskaidant tapatumo sąvoką i kelis segmentus:

1. Gamtos sukurti tapatumo ženklai. Šiame segmente reikètų išskirti kelis elementus. Pirma, nustatyti reljefo savitumus. Šie savitumai yra bene mažiausiai kintantys laike, viena pastoviausių Vilniaus tapatumo struktūros dalių, tačiau itin veikiantys urbanistinę struktūrą ir net pavienių architektūros objektų atsiradimą (Buivydas 2004). Antra, aptarti vandenis - šis gamtinis elementas yra labiau kintantis ir kartu veikiantis miestovaizdị. Pavyzdžiui, prie dabartinio VPU buvusi brasta per Nerị daro itaką kelių tinklo formavimuisi, tačiau, kai veikiant litodina mikai dingsta brasta, nunyksta ir ten vedęs kelias. Taip pat buvusi Vilnelès senvagè, juosusi dabartinę Katedros aikštę, kūrẻ kitokị erdvinị vaizdą, nei matome dabar. Svarbus ir inžinerinis vandenų vaidmuo - Župronių šaltiniai, Vingrių šaltiniai ar Aušros vartų šaltiniai sudarè prielaidas intensyvesnei urbanizacijai dèl patogaus vandens tiekimo. Trečia, aptarti augmeniją. Tai labiausiai kintantis gamtinis elementas, tačiau taip pat vizualiai pats aktyviausias, kuriantis stiprų miesto ar jo apylinkių ìvaizdị.

2. Kultūrinio konteksto savitumas. Šis segmentas pirmiausia apima politinius (politinè santvarka, valdžios pasidalijimas, valdžios efektyvumas, viešasis saugumas), ekonominius (pramonè, verslai, amatai, kuriama pridètinè vertè), kultūrinius (išsilavinimas, kutūros pasiūla ir paklausa, savo vertès ir tapatumo suvokimas), tautinius bei konfesinius (miesto gyventojų tautinè ir konfesinè sudètis, ekonominès ir politinès galios balansas), socialinius (socialinè atskirtis, socialinis teisingumas, užimtumas) aspektus. Taip pat reikia įvertinti miesto ịvaizdžio aspektą miesto gyventojų ir miesto svečių atžvilgiu (tiriant Brauno-Hogenbergo plane matomus tapatumo sluoksnius vertinamas tik miesto svečių suvokiamas įvaizdis). Šis tapatumo sąvokos elementas yra labiausiai kintantis ir nepastovus.

3. Antropogeniniai tapatumo ženklai. Šis segmentas apima žmogaus sukurtus miesto tapatumo darinius. Pirma, tai urbanistiniai dariniai: gatvés, aikštès, krantinès, kvartalai, miesto centras ir priemiesčiai. Šis segmentas turi tendenciją nekisti arba kisti labai mažai. Antra, architektūros objektai. Tai daugiausia vizualios informacijos perduodantys tapatumo elementai. Pakankamai smarkiai kintanti tapatumo struktūrinè dalis, kartu savyje koduojanti miesto istorijos informaciją - rekonstrukcijas, perstatymus, karus ir okupacijas, miesto klestejimo ir nuosmukio periodus. Prie antropogeninių tapatumo ženklų reikia priskirti ir mažosios architektūros objektus. Tai trumpalaikis, tačiau efektyviai miesto realijas atspindintis segmentas, suteikiantis informacijos apie viešosios erdvès kokybę, miesto ūkinị ir kultūrinị gyvenimą.

Toks suskaidymas pakankamas susiformuoti modeliui, pagal kurị galima tirti bet kurio regiono, laikotarpio miesto tapatumą tiek vizualioje, tiek mentalineje plotmèje.

\section{Vilniaus plano Civitates Orbis Terrarum atlase apžvalga}

Pirmas Vilniaus miesto vaizdas (1 pav.) yra išspausdintas Georgo Brauno ir Franso Hogenbergo atlaso Civitates Orbis Terarum trečiojoje knygoje (liber tertivs), pavadintoje VRBIVM PRÆCIPVARVM TOTIVS MVNDI, $1581 \mathrm{~m}$. leidime, spausdintame Kelne Teodoro Graminejjaus spaustuveje (Braun 1581). Vilnius jame pavaizduotas nuo Velnių (dabartinio Tauro) kalno. Parodytas visas (nors klaidingas) miesto gatvių tinklas, kvartalai užpildyti tikrais (arba spejamais) pastatais. Vaizdas atliktas oforto technika ir kai kuriuose leidimuose yra spalvotas. F. Hogenbergas greičiausiai niekada nebuvo Vilniuje, darbui turbūt naudojo tekstinius aprašus ir dabar neišlikusius kitų dailininkų piešinius. Netiesioginiai ịrodymai gali būti keli. Pirma, plane pavaizuotas namas Die Junge Koniginne Haus (Jaunosios kunigaikštienès namai). Jaunoji Žygimanto Augusto žmona Elžbieta fon Habsburg mire dar 1545 m., o Barbora Radvilaite (karalius su ja buvo susituokęs slapta) mire $1551 \mathrm{~m}$. Todèl galima spèti, kad vaizdai, kuriuos naudojo F. Hogenbergas, piešti karalienės aplinkos asmens gerokai anksčiau, nei publikuotas Brauno ir Hogenbergo planas. Antra, plano gatvių tinklas taip pat nèra tikslus, turbūt pieštas remiantis buvusiuoju Vilniuje arba tais pačiais ankstesniais piešiniais. Trečia, eksplikaci-

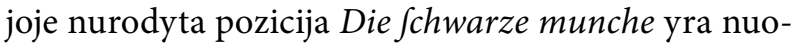
roda i juoduosius vienuolius - benediktinus, tačiau benediktinų ordino Vilniuje nèra buvę. Taigi planas aiškiai kompiliatyvinio pobūdžio. Anot V. Drèmos, tai įrodo ir kitas niuansas: visi bereikšmiai pastatai nupiešti aksonometriniu pavidalu. Tačiau svarbesni pastatai perteikti plokštuminiu vaizdu. V. Drèma knygoje „Dingęs Vilnius“ spejja, kad taip yra greičiausiai dèl to, kad autorius nedrịso išsigalvoti erdvinès kompozicijos 


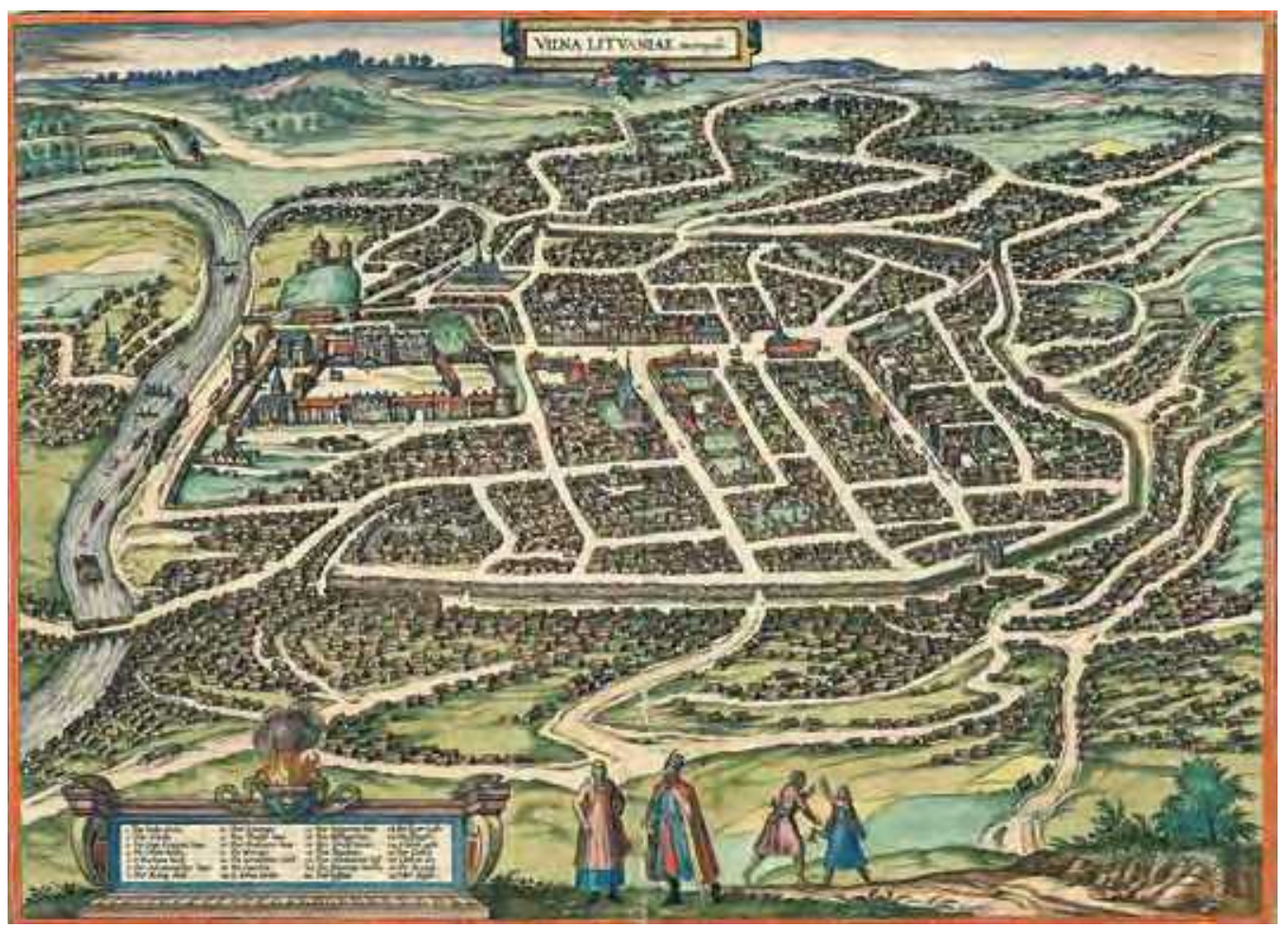

1 pav. G. Brauno atlase pateiktas Vilniaus miesto planas, $1581 \mathrm{~m}$.

Fig. 1. Vilnius city plan in the atlas of G. Braun, 1581

pats, nes šių pastatų struktūra jam buvo nežinoma. $\mathrm{V}$. Drèma iš to daro išvadą, kad visi pastatai, kuriuos dailininkas perteike plokščiai - frontaline projekcija, yra ikonografiškai tikslūs ir autentiški, o kurie pateikti aksonometrija - nevertingi ir dailininko tiksliai net ir nevaizduoti (Drèma 1991).

Kartu su žemèlapiu atlase pateikiamas ir vieno puslapio lotyniškas tekstas, nupasakojantis miesto aplinką, žmones, papročius. Dauguma deskripcijų gana negatyvios, miestiečiai aprašomi kaip barbarai, miestas - kaip nepasiekiamas ir nesaugus užsieniečiams, o konfesinè gyventojų priklausomybė vis dar smarkiai pagoniška. Keista tai, kad žemèlapio eksplikacija sudaryta vokiečių kalba, o aprašomasis tekstas - lotyniškai, tai rodo dailininko ir teksto autoriaus skirtingu laiku atliktą ir nekolegialų darbą - žemèlapis pieštas turbūt skirtingomis intensijomis, nei rengtas miesto aprašymas.

Atlase spausdintame Vilnius žemèlapyje yra 28 punktų eksplikacija (2 pav.). Dauguma minimų objektų nesunkiai identifikuojami, jų buvimas pagrịstas ir kitais istoriniais dokumentais. Kai kurie punktai pažymėti tik eksplikacijoje, tačiau nepažymèti pačiame plane, tačiau iš kasinejjimų medžiagos ir lygiagrečių istorinių šaltinių tikrai žinome juos buvus - pavyzdžiui, 5 numeriu pažymèta S. Barbara kirch. Kai kurie kiti eksplikacijoje minimi objektai nepažymetti plane: (11) Die Wersope, (20) Die Jchwarze munche, (22) Die Keur Kafte. Naudodamiesi tame pačiame atlase esančiu

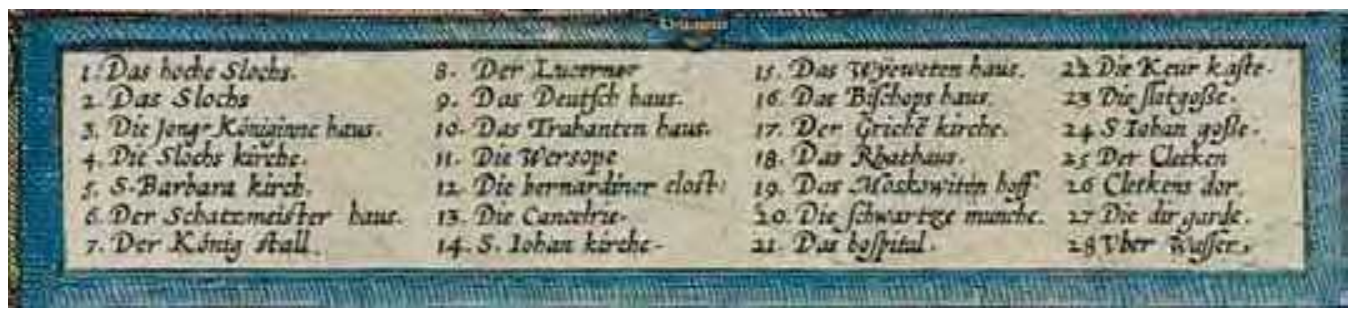

2 pav. G. Brauno atlaso Vilniaus plano eksplikacija (legenda)

Fig. 2. The legend of Vilnius city plan in the atlas of G. Braun 
tekstiniu žverryno (tekste vivarium, plane Die dir garde (Tiergarde)) aprašymu, galime padaryti tam tikras išvadas. Teksto dalis, aprašanti žveryną, skamba taip: ...In quo omnis generis ferae, sumptu permagno aluntur: vulgo VVersupa, id est, iuxta aquas, quibus vicina est, dicitur Vilnensis porro populus \& quotquot itidem suburbanas incolut casas, agrestis sunt seruilis que ingeni (...kuriame yra visokiu rüšiu žvèriu, kuriu išlaikymas labai daug kainuoja: vilniečiu liaudies šis nutolęs prie vandens esantis [žverrynas] vadinamas Vversupa, tačiau taip pat priemiesčiuose yra daug kaimiečiu gyvenamu lūšnu (incolut casas agrestis), jie yra vergai iš prigimties (servilis que ingeni)...) (vert. L. Rekevičius). Kadangi žinome Žygimanto Augusto vasaros rezidenciją buvus Viršupyje (Drèma 1991), galime susieti, kad tai ir yra plane minimas Die Wersope ir tekste minimas Vversupa. Taigi, greičiausiai tai yra ta pati vieta, kuri plane pažymèta 27 numeriu Die dir garde (Tiergarde žvėrių aptvarai). Šis Dirgarde ar Viršupis pažymètas per arti Pilių teritorijos, iš tikrųjų Viršupio rezidencija yra buvusi dabartiniame Antakalnio troleibusų žiede, maždaug $5 \mathrm{~km}$ atstumu nuo dabartinių Vilnelès žiočių. Die Jchwarze munche gali būti netikslumas - galbūt autorius taip identifikavo kitus tamsiai besirengiancius vienuolius - pranciškonus arba bernardinus. Kadangi Bernardinų vienuolynas pažymètas atskirai 12 numeriu, greičiausiai tai bus pranciškonų vienuolynas, šiame plane savo numerio neturintis.

Brauno ir Hogenbergo atlaso Vilniaus miesto planas iki šiol nagrinètas ir kitų lietuvių bei užsienio tyrinètojų, tarp kurių paminètinos J. Žalkausko, P. Reklaičio apžvalgos, lenkų tyrinètojo K. Bučeko (K. Buczek) tekstai. Šie autoriai daugiausia nagrinejo šio plano autentiškumą, lygindami su žinomais miesto architektūros istorijos faktais, gilinosi ị faktinę plane pateiktą informaciją. Iki šiol planas nèra nagrinètas miesto tapatumo, miesto ịvaizdžio požiūriu, vertinant ne tik kartografinius ar istorinius faktus, tačiau ir sudarant prielaidas menotyriniam miestovaizdžio aprašymui.

\section{Vilniaus plano analizė pagal pasirinktą tapatumo stuktūros modelị}

Plane aiškiai perteikiami gamtiniai ir antropogeniniai tapatumo elementai, o kultūrinị kontekstą galime interpretuoti pagal kai kurias detales.

Gamtiniai reljefo savitumai, matomi atlaso plane, iki šių dienų pasikeitę nedaug. Planas gana netikslus, kad būtų galima atlikti palyginimus, tačiau tikrai matosi už miesto kylantis reljefas - Neries senvagès liekanos, taip pat plane galima įžvelgti nežymų nuolydį nuo rotušès pilies link, tai irgi nepasikeitę. Reljefe ryškus elementas - itin statūs Aukštutinès pilies kalno šlaitai. Kadangi toliau plane matomas Altarijos kalvynas parodytas palyginti nestačiais šlaitais, galima sakyti, kad dailininkas pilies kalno šlaitus galbūt ir hipertrofuotai, tačiau parodè statesnius, nes jie tikrai tokie buvo (3 pav.). Šią hipotezę patvirtina ir vèliau įvykusios pilies kalno nuošliaužos, po kurių kalnas ịgijo dabartinę, natūraliau atrodančią išvaizdą. Taigi, galima teigti, kad vienas ryškiausių XVI a. Vilniaus miestvaizdžio tapatumą formuojančių reljefo elementų buvo dirbtinai stačių šlaitų Gedimino kalnas.

Antrasis gamtinis elementas - augmenija. Ypač ryškus jos nebuvimas ant to paties pilies kalno. Dabartinis vaizdas, kai kalnas apaugęs medžiais, smarkiai niveliuoja jo charakterị ir vizualiai slepia aplinkinių želdynų - Sereikiškių, Altarijos - fone. Brauno plane pavaizduotas kalnas ir visa jo aplinka yra pliki, taigi kalnas turèjo būti itin ryškus elementas ne tik dèl savo stataus reljefo, tačiau ir dèl palikto apžvalgos lauko, netrukdomo medynų (žinoma, kalno plikumas greičiausiai buvo palaikomas dirbtinai, šalinant medžius, idant nesuprastètų gynybinès charateristikos).

Kitose plano dalyse taip pat krenta ị akis želdynų trūkumas. Miesto sienos ribose nèra nei vieno (!) medžio, o už sienos matomos apaugusios Altarijos kalvos. Rytų kryptimi besidriekiančios kalvos taip pat parodytos plikos. Taigi, galima daryti prielaidą, kad miesto aplinkoje medžių iš tiesų nebuvo, greičiausiai jie buvo iškirsti ir sunaudoti miestiečių reikmėms - šildyti, statyboms, gatvèms kloti. Taip pat būtina atkreipti dèmesi i prie tvirtovių paliekamo neužstaty to ir neužsodinto ploto praktiką - viduramžių pilims būdinga palikti

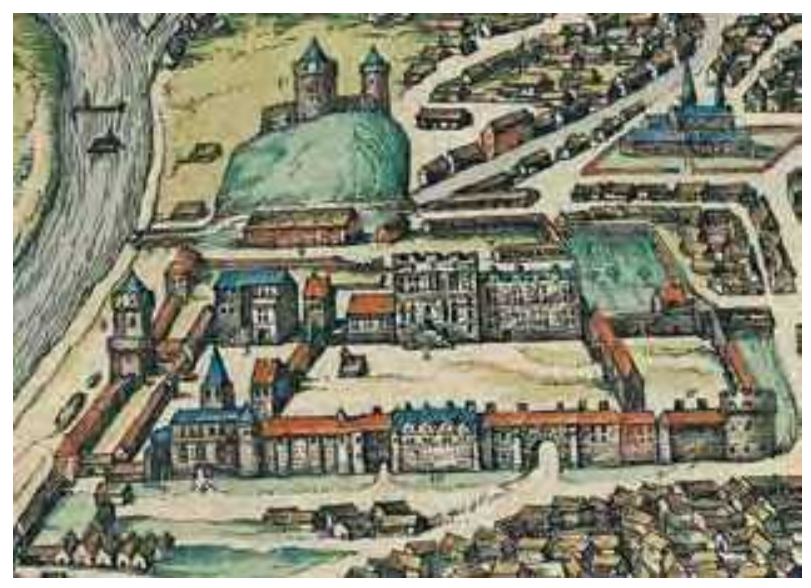

3 pav. Atlaso plane atvaizduota Vilniaus pilių teritorija

Fig. 3. Vilnius Castle complex as shown in the plan of the atlas 
apsauginę zoną priešo puolimo atveju, o taikos metu tos teritorijos būdavo naudojamos tvirtovès arkliams ir kitiems gyvuliams ganyti, tai paaiškintų bent jau želdinių trūkumą tvirtovès prieigose.

Miesto vandenys atrode kitaip nei šiandien. Pagrindinis pakitęs elementas - Vilnelè. Plane rodoma jos atšaka, ịsiterpusi tarp Žemutinès pilies ir Aukštutinès pilies kalno, tačiau tai klaidinga informacija, nes žinoma, kad Vilnelès senvagès deltos kairysis atsišakojimas buvo maždaug dabartinès Vrublevskio gatvès vietoje (Jurkštas 1990).

Kitas didelis pakitimas - Neries krantinès. Brauno atlase krantiness parody tos labai plokščios, iki pat vandens užstatytos pastatais. Žinome, kad šiandieninis vaizdas paveiktas XIX a. vykusios Žygimantų gatvès tiesimo darbų, kai miesto valdžios nutarimu buvo irengtas bulvaras (Gandrènas, Ožalas 2002) ir krantinès tapo smarkiai statesnès ir aukštesnès, tokios, kokios matomos dabar. Taip turbūt saugotasi nuo potvynių. Mažųjų vandenų Brauno atlaso plane nematyti, turbūt autorius arba neįžvelgè jų reikšmės, arba pritrūko geografinių žinių apie upelių vietas. Todèl Misionierių šaltinių, Vingrių šaltinių, Aušros vartų šaltinių, rąstinių vandentiekio vamzdynų (minimų jau nuo XVI a.) Kačergo upelio atlaso plane nesimato, nors tikètina, kad miesto ūkiniame gyvenime jie atliko svarų vaidmenị. Deja, upelių ir šaltinių nesimato ir šiandien (dèl XIX a. kanalizacijos darbų), todèl Brauno atlase peteikiame vandenų situacija nesmarkiai skiriasi nuo šiandieninès.

Brauno atlaso plane palyginti mažai tiesioginès informacijos apie miesto politinę, ekonominę, kultūrinę, socialinę, tautinę ar konfesinę aplinką. Parodyta pakankamai daug katalikiškų bažnyčių, kad būtų galima teigti mieste dominavus (bent jau kultūriškai) katalikišką̧ą konfesiją, tačiau kiti šaltiniai teigia iki 1579 m. Vilniuje buvus bent 17 stačiatikių cerkvių, taigi galima spèti, kad žemèlapyje vaizduojama situacija kryptingai kuria katalikiško miesto tapatumą, nes plane nurodyta tik viena stačiatikių bažnyčia (Der Griehe Kirche, Voskresensko, dabar nunykusi, 4 pav.) ir ta pati - ne pagrindinè to meto stačiatikių šventovè (pagrindiniais stačiatikių maldos namais buvo Šv. Dvasios cerkvè).

Jei labai sąlygiškai susietumėme tautiškumą su konfesiškumu, reiketų manyti, kad pagal Brauno atlaso medžiagą Vilnius daugiausia buvo apgyvendintas lietuvių ir lenkų, o rutènai (stačiatikiai) sudarè mažumą. Tai irgi netiesa, nes remiantis informacija apie to meto suolininkų teismo sudètị (kurią turèjo per pusę sudaryti katalikai ir stačiatikiai), galima teigti, kad rutenai sudare bent pusę Vilniuje gyvenančių krikščionių. Planas

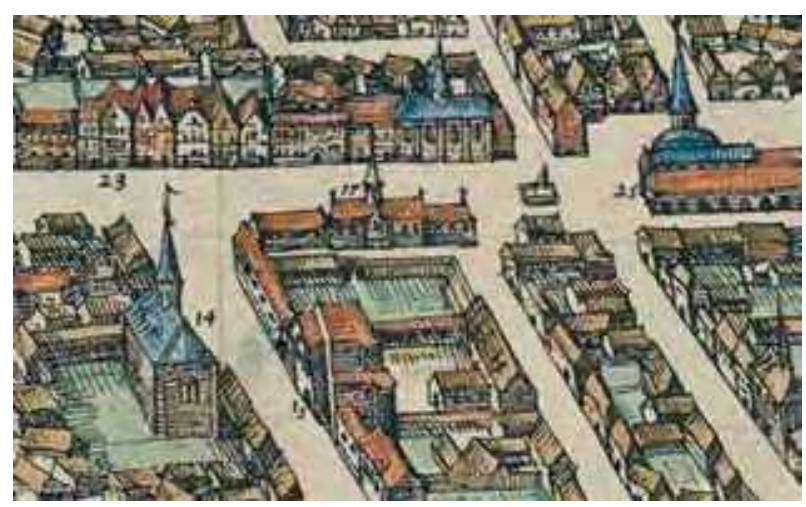

4 pav. Vienintelè plane pavaizduota stačiatikių cerkvè (17 numeris)

Fig. 4. The only Russian orthodox church in the plan of the atlas (17)

taip pat neatspindi kitų konfesijų padèties: nekalbama apie reformatus (protestantus, kalvinistus), kurie tuo metu tikrai turèjo maldos namų pačiame centre (4 pav., virš 17 numeriu pažymètos stačiatikių cerkvès), judèjus (kurių didžioji sinagoga buvo pastatyta XVI a. antroje puseje), musulmonus totorius ir karaimus, kurie greičiausiai turejo savo maldos namus. Totoriai plano tekstineje dalyje aprašomi kaip gyvenantys užmiestyje, daugiausia dirbantys vežikais arba pirkliu palydovais (vert. L. Rekevičius). Gali būti, kad kitų konfesijų pastatai nenurodyti tyčia, siekiant paryškinti katalikišką miesto charakteri.

Socialinis kontekstas Brauno plane taip pat prieštaringas. Žemèlapyje aiškiai išsiskiria tvarkingos gatvès miesto sienos viduje ir padrikas užstatymas už miesto sienos, kur gatvès neaiškių konturų, dažnai niekur nevedančios, aiškiai vargingi kvartalai. Eksplikacijoje minima ligoninè (greičiausiai špitole - vargingųjų, nebeišgalinčių elgetauti prieglauda (Žalkauskas 2010)), tačiau aprašyme rašoma atvirkščiai - kad miestas neturi pavargèliu prieglaugos, kur labdaringuju padedami galètu atgauti jeggas (nulla paupertate afflictis assignata loca, ubi misericordiae refoueantur operibus). Galima neabejoti, kad šiuo atveju klaidina tekstas, nes špitolè prie Švč. Trejybès bažnyčios buvo jau nuo XVI a. vidurio. Miesto gyventojai aprašomi kaip primityvūs ir nevalyvi, itin mégstantys gerti, nors vyno neturi, miegantys ant kietų suolų (minkštai miegoti laikyta nuodè$\mathrm{me}$ ), namuose nèra jokios puošybos ar prabangos. Taip pat gyvena ir turtingieji, tik skiriasi jų drabužiai, kurie yra puošnesni ir dabinti auksu bei sidabru. Aprašyme minima, kad jokiame kitame pasaulio mieste nèra tiek daug aklų žmonių, to priežastis - dūminiai ugniakurai namuose, o tvyrantys dūmai išgraužia akis. Miestiečiai 
neturi tvartų, gyvuliai gyvena kartu su šeimynykščiais. Šalimais ant suolo ilsisi tik ką pagimdžiusi namo šeimininko žmona, kuri po 3 ar 4 dienų turi grị̌zti prie buities darbų.

Teksto autorius išskiria Vilnios upès apsuptą rajoną (Užupį?), kurị aprašo kaip itin vargingą, esantį nuošaliau dèl savo skurdo, rajone néra gatviu, namai sustatyti be tvarkos, lyg stebuklo ar atsitiktinumo valia, tik dèl barbarišku gyventojų užgaidos (<...> Suburbia funt, quemadmodum in vrbibus bene conftitutis, varia, diuerfis difcreta nominibus, fed vno \& perpetuo quoda fuburbio Septa \& circumuallata Vilna cospicitur, vbi infinitus aedicularu numerus, nullo delectu nullo plataerum ordine, fed pro agrefti barbaroru voluntate, prout fors \& occafio tulit, quafi confitus videtur $<\ldots . .>$ (ištrauka ir atlaso aprašomosios dalies, iš lotynų k. vertė L. Rekevičius)).

Rašo, kad priemiesčių gyventojai yra vergai iš prigimties (seruilis que ingeni), tamsūs, tingūs, purvini, be laisvès troškimo. Rašo, kad šeimininkai vergus gali išlaikyti tik negailestingai su jais elgdamiesi, nes nuo gerai su tarnais besielgiančių šeimininkų vergai bėga. Miestiečiai, apsvaigę nuo midaus, šilto vyno ar alaus, lengvai veliasi i muštynes, kurios neretai baigiasi rimtais sužalojimais. Užsieniečio nužudymas nèra laikomas rimtu nusikaltimu ir žmogžudys gali lengvau išsisukti sumokèjęs 16 talerių baudą (<...> sed decem \& sex daleris vitam tunc redimunt $<\ldots . .>$ ), o jei auka palaidojama anksčiau, nei baigiasi bylos tyrimas, nusikaltèlis gali likti ir visai nenubaustas dèl ịrodymų trūkumo.

Aprašomas socialinis kontekstas gana negatyvus, pabrèžiantis miestiečių tamsumą, agresyvumą, miesto nesaugumą, gają pagonybę. Tai atspindi ir pats planas, kurio vienodų netvarkingai sustatytų vienaaukščių namelių eilès nesuponuoja minčiu apie kitokią socialinę aplinką.

Miesto ekonominė aplinka nei plane, nei aprašyme nedetalizuojama, tačiau plane išskiriamos klètys (Der Cletken, nuo sen. vokiško žodžio Glet - klètis), kitų tyrinètojų verčiamos kaip krautuvès, parduotuvès. Taigi, lyg ir nužymimas tam tikras komercinis miesto rajonas, nes kitur parduotuvès neišskiriamos nei plane, nei aprašyme. Taip pat reikia įvertinti plane rodomus Maskovijos pirklių namus (Die Moskowiten hoff; aula Rutenorum) ir Vokietijos pirklių namus (Das Deutsch haus). Šie objektai nurodo tam tikrą prekybos su rytiniais ir vakariniais kraštais intensyvumą. Aprašyme nurodyta, kuo prekiaujama Maskovijos pirklių namuose - vilkų, baltųjų lapių, leopardų, šermuonèlių, sabalų kailiais. Tai nurodo, kad prabangos prekių bent jau tranzitas buvo intensyvus, o galbūt dalis šių kailių likdavo ir Vilniuje, be to, prekybiniai ryšiai geografiškai platūs, nes nei leopardai, nei poliarinès lapès Maskvos kunigaikštystès valdose nesiveisè.

Apie kitą veiklą galima spręsti iš plane matomų malūnų Nèries pakrantėje, upe plaukiančių sielių (prekyba mediena), Vokiečių gatvèje nurodytos monetų kalyklos (Die Muntz). Teise ir poreikis kalti monetas nurodo ekonomini potencialą, XVI a. LDK buvo 3 monetų kalyklos: Vilniuje, Kaune ir Breste (Lietuvos Brastoje) (LDK kalyklos 2009).

Kalbant apie ekonominę Brauno atlaso plano sudarymo laikų Vilniaus aplinką reikia paminèti, kad tekste minimas labai sunkus patekimas į miestą. Rašoma, kad ị miestą i̇manoma keliauti tik žiemą, nes viskas aplinkui apsupta pelkių ir miškų, o nepakenčiami keliai, vedantys i miesta, praeinami tampa tik kai pelkes ir aplinkiniai ežerai pasidengia ledu.

Politinis kontekstas Brauno atlaso plane atskleistas šykščiai. Matyti, kad plane dominuoja pilių teritorija, taigi pabrèžta karaliaus valdžia. Taip pat legendoje išskirtas Vyskupo namas (16 numeris - Das Bischops Haus), be to, tekste nurodyta, kad Vilnius yra Lietuvos Vyskupijos centras (ampla Episcopalis Lithuaniae), taigi nurodomas ir kaip dvasinès valdžios vietinis centras. Plano legendoje taip pat išskirtas Vaivados namas (15 numeris - Das Wyeweten Haus). Vilniaus vaivada atliko pareigas keliose dabartinių apskričių (Vilniaus, Utenos, Panevėžio) teritorijose ir žemèse dabartinèje Baltarusijoje, taigi tai buvo svarbi pareigybè, o vaivada miesto kasdieniame gyvenime atliko svarbų vaidmenị. 18 numeris Das Rathaus plano eksplikacijoje reiškia rotušę, magistrato valdžios centrą. Taigi politiškai Vilnius buvo ịvairių lygių valdžios organų koncentratas - magistrato, vaivadijos, vyskupijos ir LDK sostinès, o šių institucijų darbuotojai sudarè nemenką Vilniaus elito dalį, kaip ir jų lankytojai - nemenką miesto svečių procentą (Ragauskas 2002).

Daugiausia vizualios informacijos Brauno atlaso plane pateikta apie antropogeninius tapatumo elementus: urbanistinę miesto struktūrą, architektūros objektus. Papildant netikslią plano informaciją tekstineje dalyje aprašytais savitumais, galime susidaryti apytikslį urbanistinio Vilniaus darinio vaizdą, tiesa, per F. Hogenbergo ir G. Brauno prizmę.

Plane ryškiai matomi ryškūs urbanistiniai miesto savitumai. Pirmiausia pastebimas miesto policentrinis spidulinis charakteris (tiesa, plane spinduliškumas smarkiai iškreiptas ir miesto gatvių tinklas atrodo beveik stačiakampis), susidedantis iš administracinio miesto centro - rotušès, ir administracinio valstybès centro - pilies. Aplink šias ašis mezgasi spidulinis gatvių tinklas, kurị lemia ị visas kryptis besišakojantys $\mathfrak{i}$ 
miestą vedantys keliai. Pažymètina, kad plane gatvès atvaizduotos pakankamai plačios, bet tai nesutampa su archeologinių tyrinejjmų duomenimis (Vilniaus archeologijos... 2007). Todèl būtų galima daryti išvadą, kad miesto gatvių platumas yra tik dailininko pasirinkta išraiškos priemonė, leidžianti tiksliau atskleisti miesto pastatų fasadus ir išryškinti gatvių tinklo charakteri (tegul ir neiteisingą).

Išsiskiria didžiosios miesto masės koncentracija kairiajame Neries krante, kairioje Vilnelès tèkmès pusejje, miesto išsidèstymas Neries senvagès ribose, jis beveik neįsiterpia i̇ aplinkines kalvas. Ryškus tūrinio erdvinio charakterio bruožas yra miesto siena (5 pav.). Nors nupieštas netiksliai, aiškiai matoma koncetruotas užstatymas su aiškiu gatvių tinklu intramuros ir padrika, negausiai užstatyta, reguliaraus gatvių tinklo neturinti extramuros aplinka. Priemiesčių chaotiškas charakteris paaiškinamas ir teksto užuominomis, kad kiekvienas panorèjęs gali pasistatyti sau pušinę lūšng niekieno neatsiklausdamas, taigi greičiausiai atskirų sklypų priemiesčių lūšnynai neturèjo arba (greičiausiai) dèl žemès savininko malonès (ir galbūt mokesčio) stovedavo stambesnio žemvaldžio valdoje (jursdike).

Kvartalai užstatyti daugiausiai išoriniu perimetru, kvartalų viduje intensyvumas mažesnis arba pastatų visai nèra.

Išsiskiria miesto sienos viduje atvaizduotų pastatų architektūra. Matomas gotikinis miesto charakteris, kai kurie pastatai akivaizdžiai mūriniai (arkinemis angomis. İdomus miesto savitumas - pastatais užstatytas tiltas per Nerị (dabartinis Žaliasis)). Dauguma pastatų parodyti vieno aukšto, dvišlaičiu stogu, be priklausinių (nes, anot teksto, gyvuliai buvo laikomi namuose). Kai kurie pastatai pakankamai aukšti - Vokiečių, Pilies gatvèse matomi 4 aukštų pastatai. Išsiskiria užstatymo intensyvumas upių pakrantèse - namai rodomi prie pat vandens.

\section{Vilniaus miesto vaizdavimas kitu atlase pavaizduotų miestų kontekste}

Itin įdomių įžvalgų galima pateikti lyginant Vilniaus planą iš Brauno atlaso su kitais tų pačių leidimo metų (Braun 1581) aprašytais miestais pagal D. Wood siūlomą metodiką (Wood 1992). III atlaso leidime spausdinti šie miestai: Bristolis, Česteris, Dordrechtas, Enkhuizenas, Edinburgas, Franekeris, Grenoblis, Karaliaučius, Landshutas, Leuvardenas, Leuvenas, Norvičas, Orvietas, Pasau, Ryga, Reimsas, Vilnius, Veimaras, Ciurichas. Detalesniam palyginimui pasirinkti Edinburgo (nes tai vienintelis III leidimo atlase vaizduojamas miestas, kuris kartu su Vilniumi turi prieraša „,metropolis"), Karaliaučiaus (nes tai geografiškai netolimas, strategiškai visomis prasmèmis svarbus miestas, taip pat sostinè), Ciuricho ir Grenoblio miestai. Ciurichas palyginimui pasirinktas dèl to, kad Miunsterio „Kosmografijos“ leidinyje Vilniui ir Ciurichui iliustruoti panaudoti tie patys paveikslai, lyg miestai būtų kažkuria prasme tapatūs, o Grenoblis pasirinktas dèl panašaus su Vilniumi bažnyčiu skaičiaus - nes dauguma kitų miestų jų turi mažiau.

Palyginimas atskleide įdomius rezultatus, kuriuos galima įvertinti toliau pateikiamoje lenteleje. Surašyti kiekviename plane suskaičiuotų pastatų kiekiai - atskirai išskiriant mūrinių namų skaičių, medinių namų skaičių ir kulto pastatus. 1 lenteleje įrašyti skaičiai turi

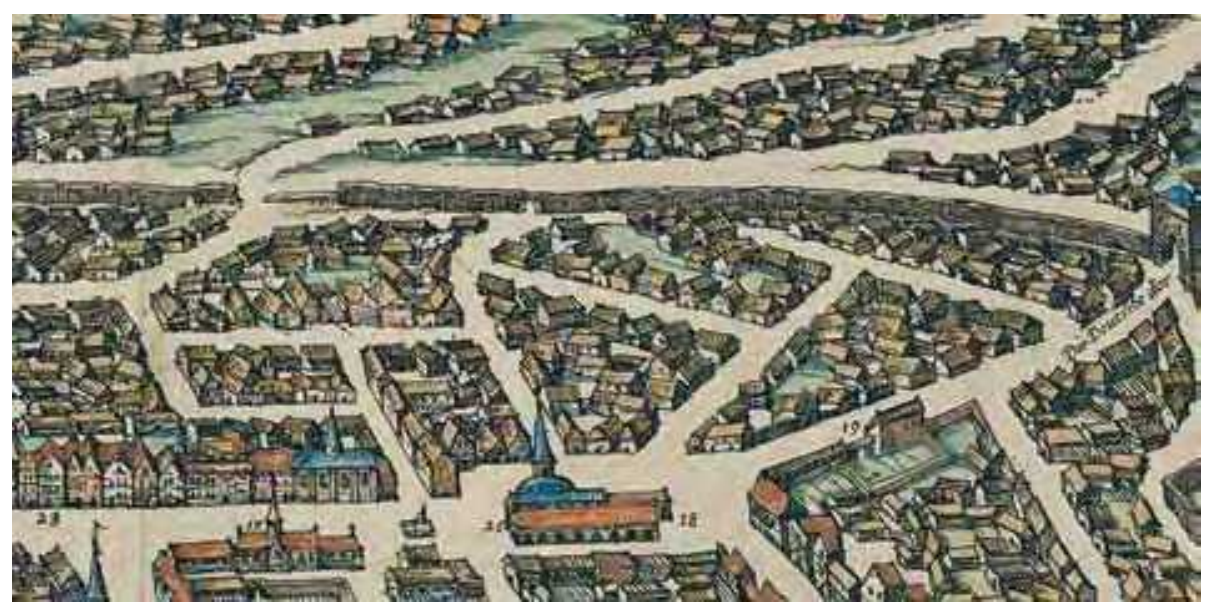

5 pav. Rotušè (25 numeris). Miesto siena. Rusų (rusinu) miestas (Civitas Rutenicum)

Fig. 5. City Hall (25). City Wall. Ruthenian city (civitas ruthenicum) 
tam tikrą paklaidą, nes dèl smulkių detalių kartais neimanoma atskirti, ar pastatas mūrinis, ar medinis, ir tenka spèti. Taip pat kaip kulto pastatai itraukti visi smailes turintys pastatai, išskiriant rotušių pastatus, tačiau neįvertinant, kad kitos įstaigos mieste taip pat gali turèti pastatus su bokštais.

1 lentelè. Atlase pateiktu Vilniaus, Karaliaučiaus, Ciuricho, Edinburgo ir Grenoblio miestų palyginimas

Table 1. Comparison of Vilnius, Konigsberg, Zurich, Edinburgh, Grenoble plans in the atlas

\begin{tabular}{lrrr}
\hline Miestas & $\begin{array}{r}\text { Mūrinių } \\
\text { namu } \\
\text { skaičius }\end{array}$ & $\begin{array}{r}\text { Medinių } \\
\text { namu } \\
\text { skaičius }\end{array}$ & $\begin{array}{r}\text { Kulto } \\
\text { pastatu } \\
\text { skaičius }\end{array}$ \\
\hline Ciurichas & 781 & & 4 \\
\hline Edinburgas & 362 & & 2 \\
\hline Grenoblis & 483 & & 18 \\
\hline Karaliaučius & 553 & & 4 \\
\hline Vilnius & 121 & 2401 & 13 \\
\hline
\end{tabular}

Galima pastebėti, kad Vilnius parodytas kaip vienas didžiausių $1581 \mathrm{~m}$. leidimo atlaso miestų. Taip pat galima teigti, kad civilizacijos pažanga Vilnius smarkiai atsilieka, nes dauguma pastatų čia yra mediniai, o kitų lyginamų miestų didžioji dauguma pastatų parodyti mūriniai.

Idomu, kad Vilnius turi palyginti didelį bažnyčių skaičių, smarkiai viršijantị kitų miestų kulto pastatų skaičių, čia nusileidžiama tik Grenobliui, kuris turi 18 kulto pastatų. Reikia atkreipti demesí, kad dauguma Vilniaus kulto pastatų labai nedaug išsiskiria iš aplin- kinių pastatų konteksto (išskyrus stambius Katedros, Bernardinų komplekso, Šv. Jono bažnyčios statinius), dažna Vilniaus bažnyčia vaizduojama kaip stambus pastatas su kyšančia smaile, o kituose lyginamuose miestuose bažnyčios vaizduojamos hipertrofuotai padidintos, pabrèžiant gotikinị dominuojantị charakteri.

Reikia pabrèžti, kad gausus Vilniaus priemiesčių užstatymas yra unikalus, nes kitų miestų už sienos esančios dalys yra beveik neužstatytos. Tai svarbus Vilniaus savitumas, nes kituose miestų planuose už miesto sienos pastatų yra labai mažai. Net Karaliaučiaus, kuris neturèjo miesto sienos, plane miestas labai koncentruotas, aiškių kontūrų, neamorfiškas - priešingai negu Vilnius.

Taip pat reikia atkreipti dèmesį, kad visų kitų lyginamų mestų planuose už miesto rodomi intensyviai dirbami laukai: smulkiai padalinti rěželiai žemès, rodomi skirtingomis spalvomis (galima spetti, kad kai kurie jų pūdymuoja, kai ūkininkaujama pagal trilaukę sistemą, arba tiesiog auginamos skirtingos kultūros). Vilniaus planas nesuteikia jokios informacijos apie aplinkinių laukų dirbamumą, miesto aprūpinimą maistu.

Krenta ị akis tai, kad Vilniuje gana vangiai išnaudojamas vandens ūkis. Kituose lyginamuose miestuose (išskyrus Edinburgą) demonstruojama intensyvi veikla vandenyje: gaudyklès, užtvaros, lieptų sistemos su pastatais, užstatyti tiltai (6 pav.). O Vilniuje matomas vos vienas tiltas (dabartinis Žaliasis), tiesa, užstatytas pastatais.

Kariniai Vilniaus įtvirtinimai atrodo gana primityviai. Miesto siena parodyta vietomis apgriuvusi, neaiškios formos, be bastionų ir kampinių bokštų (5 pav.).

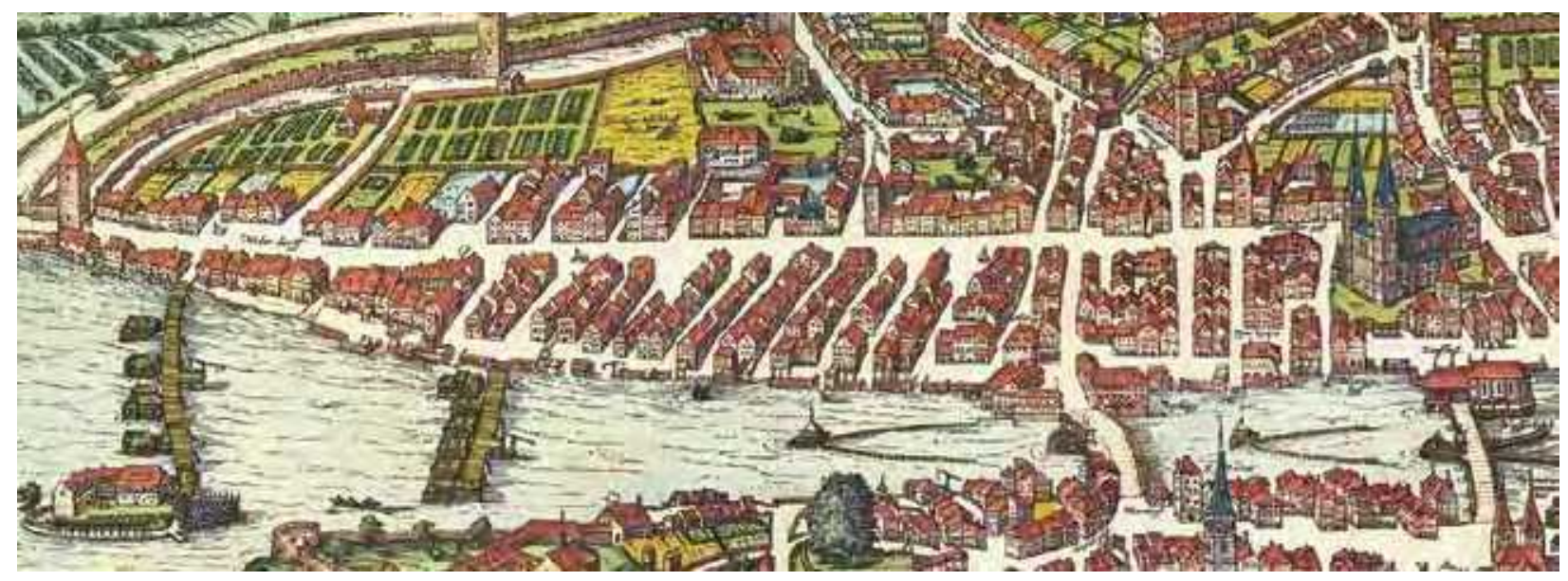

6 pav. Ištrauka iš $\mathrm{G}$. Brauno atlaso Ciuricho plano. Centrinè miesto dalis

Fig. 6. Fragment of the Zurich plan from the atlas of G. Braun. Central part of the city 
Kitų miestų (išskyrus sienos neturejjusị Karaliaučių) itvirtinimai atrodo gerokai rimčiau: Ciurichas itin smarkiai fortifikuotas, panaudojant vandeni, dvigubas gynybines sienas, daug gynybos bokštų; Grenoblis itvirtintas dviguba miesto siena, kurios kiekviena dalis turi po vandens fosą, parodyta daug bokštų (7 pav.).

Edinburgas, nors ir apjuostas primityvia siena, tačiau ši yra tvarkingos geometrijos, su 12 gynybos bokštų per visą perimetrą ( 8 pav.). Karaliaučius, nors ir neturi miesto sienos, tačiau jo centrine dalis ịtvirtinta sumaniai panaudojant vandeni ( 9 pav.). Peršasi išvada, kad arba Vilnius buvo ịtvirtintas gerokai prasčiau nei Vakarų Europos miestai dèl vietinių fortifikatorių nekompetencijos, arba taip tikslingai suformuotas miesto ịvaizdis, pabrežiant miesto nesaugumą, atsilikimą ir barbariškumą.

Idomiausias ir daugiausia interpretacijų reikalaujantis faktas yra akivaizdus Vilniaus didumas, skaičiuojant pagal pastatų ir maldos namų kieki. Ar tikrai kiti lyginamieji miestai buvo daug mažesni? Ar racionalūs mūriniai kelių aukštų namai tiesiog talpino gerokai daugiau gyventojų? Ar Vilniaus miesto planas yra tarsi ditirambas miesto didybei (tikrai ar tariamai - reikia nepamiršti, kad tikrasis planas greičiausiai buvo pieštas

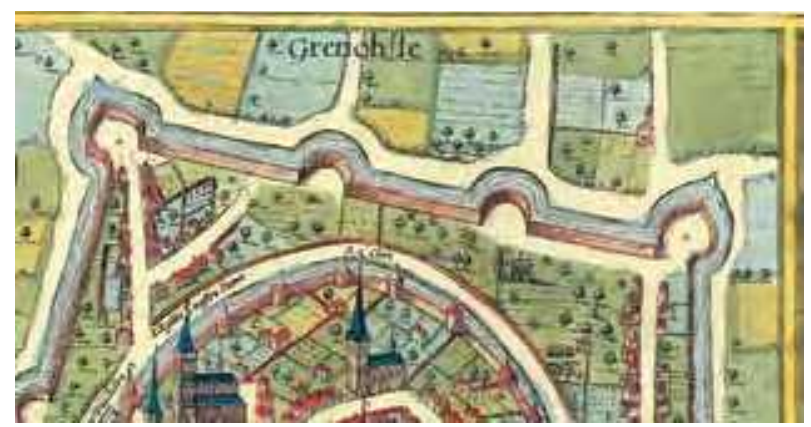

7 pav. Grenoblio plano ištrauka

Fig. 7. Fragment of the plan of Grenoble

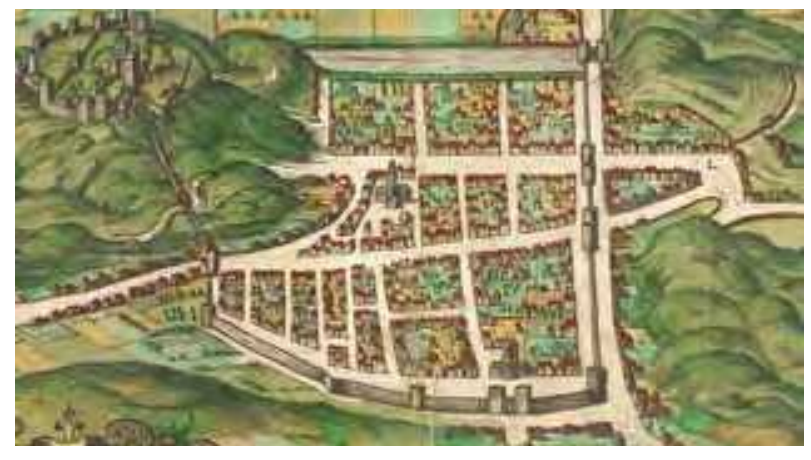

8 pav. Edinburgo plano ištrauka

Fig. 8. Fragment of the plan of Edinburgh
Žygimanto Augusto pirmosios žmonos Elžbietos von Habsburg - jaunosios karalienès - palydos asmens)?

Labiausiai tikètina versija visgi galètų būti tokia: Vilnius buvo reikšmingas ekonominis, politinis vienetas, greičiausiai išsiskiriantis ir savo dydžiu (atkreipkime dèmesị i užrašą „Metropolis“ prie miesto pavadinimo). Gali būti, kad Kelne Vakarų kartografai tiesiog pritrūko orientyrų: aplinkui buvo mažai kitų didelių miestų, nebuvo jokių išskirtinių reljefo tapatumo ženklų - kalnų, krioklių, jūrų, ežerų, miestas negarsejjo (bent jau to nepatvirtina dokumentai) jokiais gaminiais, amatais ar prabangos prekemis. Kartu tai buvo svarbus Vakarų civilizacijos rytinio pakraščio riboženklis: katalikiškų teritorijų pabaiga, už kurios plytëjo neįvardintos Rusios žemès, mongolų ordos, stačiatikybė; Vilnius buvo antermurale christianitatis, ir tokia išskirtinè kultūrinè, geografinè ir politinè pozicija sukurstė kartografų vaizduotę nupiešti miestą tokio dydžio, kokio jis galbūt nè nebuvo (Briedis 2009: 54). Tokio kultūrinio požiūrio apraiškas į žemèlapių sudarymą viduramžiais ir Renesanso laikotarpiu pateikia ir žemèlapių tyrinètojas D. Wood, ypač akcentuojantis epochai ịprastą praktiką dirbtinai išpūsti ir padidinti su krikščionybe ar katalikybe susijusius aspektus kitų kultūrų atžvilgiu, jas sumenkinant.

Todel Brauno ir Hogenbergo atlase kuriamas Vilniaus įvaizdis yra nevienareikšmis. Regis, autoriai neturi intensijos pagrąžinti tikrovès - aplink miestą nerodomi dirbami laukai, nemaskuojami tušti plotai miesto viduryje, nèra smarkiai išryškintos bažnyčios, o planą lydintis tekstas yra itin kritiškas. Tačiau miestas rodomas tikrai didelis palyginti su kitais miestų planais, ir jis ịvardinamas kaip „Metropolis“. Galima daryti prielaidą, kad autoriai nėra įkvèpti Vilniaus kultūros, tačiau pripažista jo reikšmę ir charakterizuoja miesto reikšmę jo dydžiu. Kritiškas planą lydintis tekstas tikrai leidžia suprasti, kad tai nèra miesto pa-

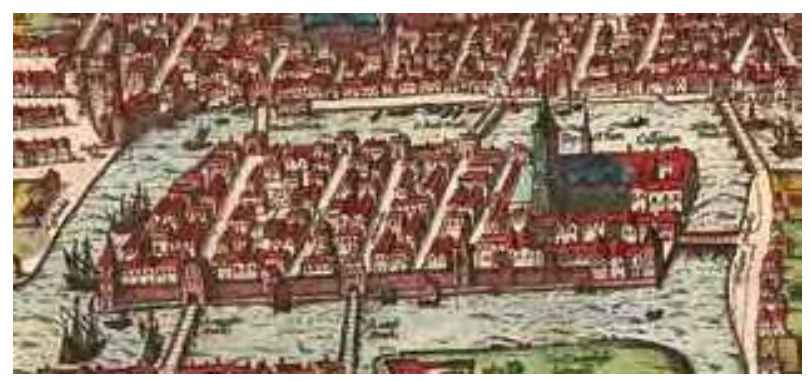

9 pav. Centrine ịtvirtinta Karaliaučiaus dalis. Ištrauka iš Karaliaučiaus plano

Fig. 9. Central fortified part of Konigsberg. Fragment of the plan of Konigsberg 
negirika. Taigi šis planas leidžia ịvertinti ir kuriamą Vilniaus miesto įvaizdi - svarbus ir didelis komercinis metropolis, tačiau netiesiogiai parodoma, kad ji atsilikęs technologiniu (nerodomi spalvoti dirbamos žemès plotai - trilaukè, pažangiausia tų laikų žemdirbystès sistema), kultūriniu, karybos požiūriais.

İdomu palyginti Vilnių su kitu stambiu LDK centru Gardinu (10 pav.), kuris pakliuvo į II-ąjí atlaso leidimą $1575 \mathrm{~m}$. Gardinas buvo svarbus miestas, kuriame vykdavo bendri Lietuvos ir Lenkijos seimai, tyrinètojų ívardinamas kaip antras pagal svarbą LDK miestas (Kamuntavičius 2007). Gardinas buvo šalia tuo metu judraus kelio Vilnius-Varšuva ir buvo pirmasis stambus LDK miestas, kurị pamatė ị Vilnių iš Vakarų per Varšuvą vykstantis keliautojas. Brauno atlase, suskaičiavus pastatus, gaunamas toks Vilniaus ir Gardino palyginimas (2 lentelè).

2 lentelè. G. Brauno atlase pateiktų Vilniaus ir Gardino miestų palyginimas

Table 2. Comparison of Vilnius and Grodna plans in G. Braun atlas

\begin{tabular}{lrrrr}
\hline Miestas & $\begin{array}{r}\text { Mūriniai } \\
\text { namai }\end{array}$ & $\begin{array}{r}\text { Mediniai } \\
\text { namai }\end{array}$ & $\begin{array}{r}\text { Kulto } \\
\text { pastatai }\end{array}$ & Pilys \\
\hline Gardinas & 18 & 102 & 5 & 2 \\
\hline Vilnius & 121 & 2401 & 13 & 2 \\
\hline
\end{tabular}

Matosi, kad Brauno atlase pavaizduotas Vilnius labai smarkiai lenkia antra pagal svarbuma $L D K$ miestą (Kamuntavičius 2007) - Gardiną. Mūrinių pastatų parodyta beveik 7 kartus daugiau, medinių namų 24 kartus daugiau, bažnyčių 2 kartus daugiau. Galima tik spèlioti, ar tokie skirtumai atsiranda dèl neiprastos Gardinui atvaizduoti pasirinktos perspek-

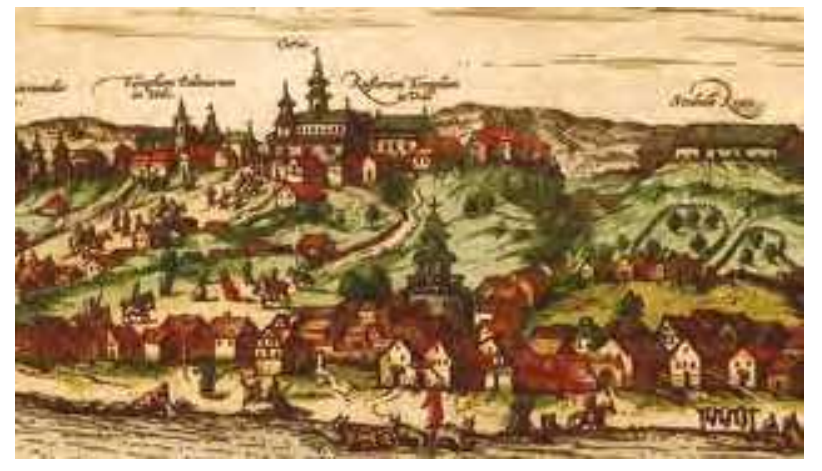

10 pav. Gardino centrinè dalis. Ištrauka iš $G$. Brauno atlaso plano

Fig. 10. Central part of Grodna. Fragment of the plan in G. Braun's atlas tyvos, ar autorius sąmoningai Gardiną sumažino dèl R. Kamuntavičiaus minimo labai neigiamo Gardino atvaizdavimo užsieniečiu aprašymuose. Galbūt faktas, kad Gardinas nebuvo administracinis centras, o prekybos požiūriu buvo labiau tranzito taškas, lèmé, kad miestas iš tiesų buvo gerokai mažiau išsivystęs už Vilnių.

\section{Apibendrinimai}

1. Brauno atlaso žemèlapis yra dokumentiškai netikslus, tačiau vertingas ir informatyvus miestovaizdžio savitumų studijoms, tiriant miesto tapatumą ir ìvaizdị. Brauno atlaso planas ir jo aprašomoji dalis yra rengti ne vienu laiku ir galbūt skirtingomis intensijomis, smarkiai paryškinant autoriams ịsiminusius savitumus.

2. Planas perteikia daugumą tapatumo aprašymo modelio aspektų: gamtinès aplinkos savitumus, urbanistinius savitumus (nors ir ne visai tiksliai). Architektūriniai objektai pavaizduoti gana netiksliai, tačiau ryškiai perteikia autoriaus suvoktą miesto įvaizdị. Daugiausia informacijos apie kultūrinius konteksto savitumus suteikia planą lydintis tekstinis aprašas.

3. Miestas pavaizduotas didelis, tačiau menkai išsivystęs, daugiausia medinis, geometriškai netaisyklingos struktūros, su padrikai įrengta gynybine siena. Dauguma patatų mediniai, vieno aukšto sustatyti padrikai, nesilaikant perimetro. $0,5 \%$ visų pastatų galima spèti buvus mūriniais, dviejų ir daugiau aukštų. Svarbią vietą miesto struktūroje užima pilių teritorija, tačiau matosi miesto policentrinis charakteris.

4. Plane atskleidžiamas Vilniaus kaip sostinès statusas, rodomi ịvairių lygių administraciniai centrai, kelių šalių atstovybès (ambasados, prekybos namai?), tačiau suteikiama mažai žinių apie miesto ekonominį, politinị, kultūrinị kontekstą, o atspindèta konfesinė situacija yra vienpusiška katalikų atžvilgiu ir neparodo tikrosios to meto tautinès bei religinès padèties. Taip pat Vilniaus socialinis ir kultūrinis kontekstas perteiktas labai neigiamai, gyventojai parodyti kaip neišsilavinę, barbariški, grubūs, o miestas nesvetingas ir sunkiai pasiekiamas užsieniečiui.

5. Tačiau planu ir tekstu kuriamas miesto įvaizdis yra platesnio paveikslo, kuris atsiskleidžia lyginant Vilnių su kitu miestu atvaizdais, dalis. Nustatoma, kad Vilniaus dydis, skaičiuojant pagal planuose rodomus pastatus ir visuomeninius objektus - bažnyčias - gerokai lenkia kitus miestus, tačiau atsilieka 
nuo jų civilizuotumu, mūro pastatų kiekiu, tvarkingu miesto planavimu, gynybinių sistemų kokybe. Tačiau lyginant Vilnių su kitu atlase pateiktu LDK miestu Gardinu, matomas akivaizdus kokybinis ir kiekybinis pranašumas.

6. Gali būti, kad Vilniaus dydis, matomas žemèlapyje, yra kartografo susidaryto įvaizdžio atspindys: stokodamas kitų ryškių orientyrų, suvokdamas Vilnių kaip vakarietiškos civilizacijos ir katalikybès kraštinị forpostą, F. Hogenbergas padidintai atvaizdavo savo suvoktą miestą.

\section{Literatūra}

Braun, G. 1581. VRBIVM PRACIPVARVM TOTIVS MVNDI. Cologne: Typis Theodori Graminaei.

Briedis, L. 2009. Vilnius: City of Strangers. Vilnius: Baltos lankos.

Buivydas, R. 2004. Vilniaus Senamiestis: semantinis gamtos elementų vaidmuo, Urbanistika ir architektūra XXVIII (1): 3-8.

Drèma, V. 1991. Dingęs Vilnius. Vilnius: Vaga.

Gendrènas, G.; Ožalas, E. 2003. Karaliaus Mindaugo tilto prieigos. Žvalgomieji archeologiniai tyrimai. Kairysis Neries krantas [interaktyvus]. Pilių tyrimo centras „Lietuvos pilys" [žiūrèta 20100128 ]. Prieiga per internetą: <http:// www.lietuvospilys.lt/data/zygimantu.htm>.

Jurginis, J.; Šidlauskas, A. 1988. Kraštas ir žmonès. Lietuvos geografiniai ir etnografiniai aprašymai (XIV-XIX a.). Vilnius: Mokslas.

Jurginis, J.; Merkys, V.; Tautavičius, A. 1968. Vilniaus miesto istorija nuo seniausiu laiku iki Spalio revoliucijos. Vilnius: Mintis.

Jurkštas, J. 1990. Senojo Vilniaus vandenys. Vilnius: Vaga.

Kamuntavičius, R. 2007. Kijevas Žemaitijoje: Kaunas Vakarų Europos XVII a. leidiniuose, Istorija: Lietuvos aukštuju mokyklu mokslo darbai, 68: 21-29.

Katalynas, K.; Vaitkevičius, G. 1995. Vilniaus miesto raida XIV-XVII amžiais, Baltų archeologija 4(7): 25-32.

LDK kalyklos [interaktyvus]. 2009. Lietuvos nacionalinis muziejus [žiūrèta 20100128 ]. Prieiga per internetą: <http:// www.lnm.lt $/$ index.php?option $=$ com_content $\&$ task $=$ view \&id=151\&Itemid=301>.

Norberg-Schulz, C. 1980. Genius Loci: Towards a Phenomenology of Architecture. New York: Rizzoli.

Petrušonis, V. 2003. Vietovès kultūrinio tapatumo semantinio modelio struktūra, Urbanistika ir architektūra XXVII(3): 99-110.

Ragauskas, A. 2002. Vilniaus miesto valdantysis elitas XVII a. antrojoje puseje. Vilnius: Diemedis.

Rèklaitis, P. 1999. Du Vilniaus vaizdai XVI-XIX amžių grafikoje, iš Prarastosios Lietuvos pédsaku beieškant. Vilnius, 189-205.

Vilniaus archeologijos atlasas. 2007. Lietuvos istorijos instituto DVD. Vilnius: LII.
Vilniaus senojo vandentiekio vandenvietes [interaktyvus]. 2009. UAB Vilniaus vandenys [žiūrèta 201001 28]. Prieiga per internetą: $<$ http://www.vv.lt/lt/apie/istorija/vandenvietes/>.

Wood, D. 1992. The power of maps. New York: Guilford Press.

Žalkauskas, J. 1973. Vilnius Brauno ir Hogenbergo atlase [interaktyvus] [žiūrèta 201001 28]. Prieiga per internetą: $<$ http://www.aidai.us/index.php?option=com_content\&ta sk=view\&id=975\&Itemid $=133>$.

\section{THE LAYERS OF VILNIUS IDENTITY IN THE ATLAS OF BRAUN AND HOGENBERG}

\section{Rekevičius}

Abstract. The paper analyses the layers of Vilnius identity revealed in the city atlas of Braun-Hogenberg. The information of the text and graphical figures is reviewed through a certain model of the structure of identity. Attempts are made to find natural (relief, waters, flora), cultural (political, economic, social, etnical-confessional) and anthropogenical (urban, architectural) peculiarities of Vilnius city, rendered in the atlas, and compare it with the other cities from the same source. The paper reveals the peculiarities of urban situation, the types and morfology of buildup, city poly-central character and features of capital city, characterization of citizenry as well as inaccuracies on confessional balance, network of streets, size of the city.

Keywords: Braun-Hogenberg atlas, Vilnius Old Town, peculiarity, identity, image.

\section{LUKAS REKEVIČIUS}

Master of Architecture, PhD student, Dept of Fundamentals and Theory of Architecture, Vilnius GediminasTechnical University (VGTU), Pylimo g. 26/Traku g. 1, 01132 Vilnius, Lithuania.

Research interests: cultural geography, heritage development, urban identity, city image. 